\title{
Framing a Bilateral US-Russian Geologic Repository Initiative
}

Leslie J. Jardine

September 8, 1998

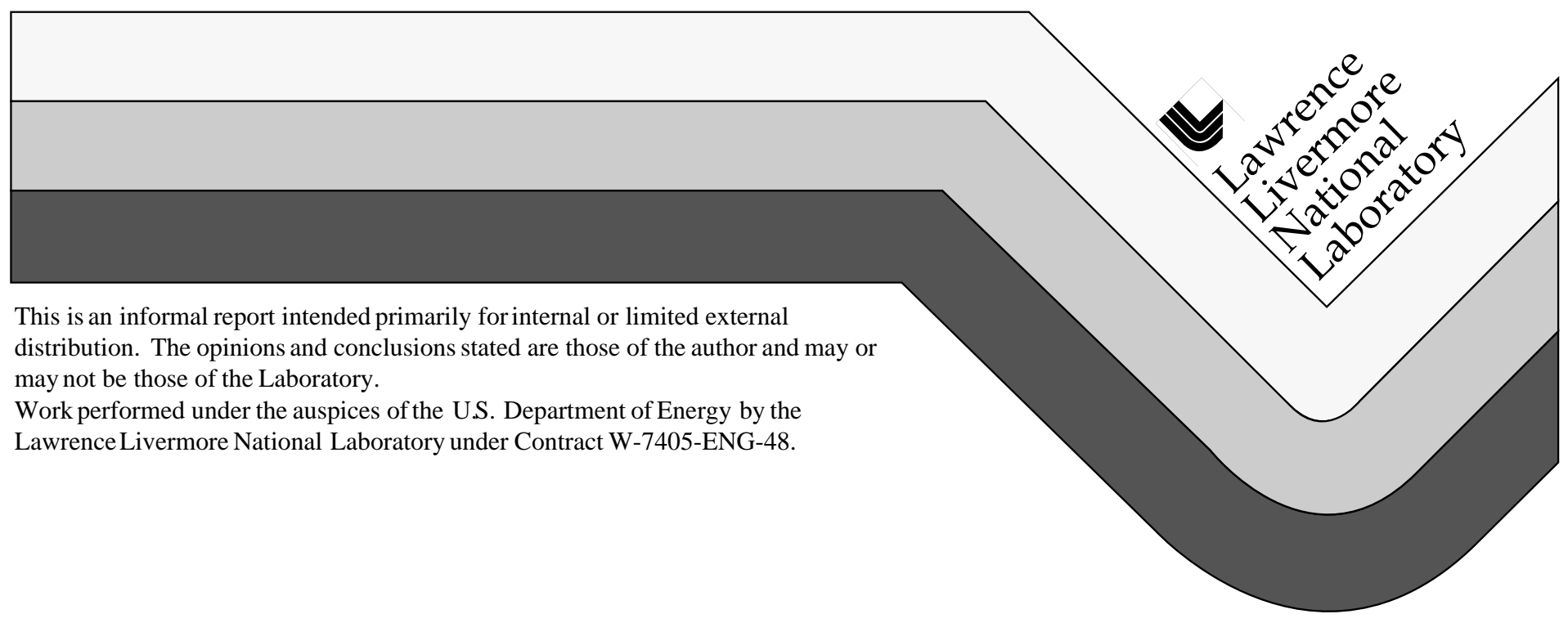




\section{DISCLAIMER}

This document was prepared as an account of work sponsored by an agency of the United States Government. Neither the United States Government nor the University of California nor any of their employees, makes any warranty, express or implied, or assumes any legal liability or responsibility for the accuracy, completeness, or usefulness of any information, apparatus, product, or process disclosed, or represents that its use would not infringe privately owned rights. Reference herein to any specific commercial product, process, or service by trade name, trademark, manufacturer, or otherwise, does not necessarily constitute or imply its endorsement, recommendation, or favoring by the United States Government or the University of California. The views and opinions of authors expressed herein do not necessarily state or reflect those of the United States Government or the University of California, and shall not be used for advertising or product endorsement purposes.

This report has been reproduced directly from the best available copy.

Available to DOE and DOE contractors from the Office of Scientific and Technical Information P.O. Box 62, Oak Ridge, TN 37831

Prices available from (423) 576-8401

Available to the public from the National Technical Information Service

U.S. Department of Commerce 5285 Port Royal Rd. Springfield, VA 22161 


\section{Framing a Bilateral US-Russian Geologic Repository Initiative}

\section{Introduction}

This document summarizes a framework for the development of a bilateral United States-Russian geologic repository initiative to enable cooperative work on the science and technology of geologic disposal of high-level nuclear wastes and fissile-containing materials. Three different types of integrated technical activities in Russia are employed to focus and organize a Department of Energy (DOE) Office of Civilian Radioactive Waste Management (RW) FY00 initiative. We have specified the items for initial negotiations with the Russians for start-up activities in FY99 and early FY00. These first interactions will generate other activities which, by utilizing Russia's unique capabilities, may assist us in the development and validation of the US geologic repository program. The current International Science and Technology Center (ISTC) cooperative study of 30 years of heat effects on underground hardrock rock media at the closed city of Krasnoyarsk-26 (Zheleznorgorsk) is but one example of such a Russian geologic repository analogue project that may assist the US geologic repository program.

\section{Objectives}

The overall program objective is to develop and implement a formal US-Russian bilateral cooperative geologic repository program for radioactive wastes and fissile-containing materials. The US objectives are derived from the need to advance international repository options, from national security objectives, and from non-proliferation interests, since the program will employ former weapons scientists and engineers in Russia while further consolidating and securing fissile nuclear materials within Russia. Specifically, the objectives include:

- Contributing to solving international technical problems by fostering repository research

- Redirecting technical talents to peaceful activities with a future worldwide technical need

- Integrating former weapons scientists and engineers into the global scientific community

- Assisting in transition to customer and market driven economics.

\section{Implementation and Support}

We propose to provide US support with emphasis on Russian Institutes and Industrial Enterprises involved in former weapons-related work. As shown in Table 1, FY99 startup requires \$0.4 million to develop the joint strategy, logic, an implementing program plan, and to identify the specific Russian participants. This leads to a FY00 budget of $\$ 2.8 \mathrm{M}$, of which a maximum of $\$ 2 \mathrm{M}$ is to be spent in Russia, and reasonably constant budgets thereafter, not exceeding $\$ 4 \mathrm{M}$ in Russia until after 2004. The portion spent in the United States will be limited to a small fraction $(<\sim 1 / 3)$ of money budgeted for expenditure in Russia after the initial FY99 program planning and startup. Initial project activities would assess the suitability of multiple site options, but project activities would most likely be quickly focused to one specific region and a single site in Russia (e.g., a granite hardrock site, the Nizhnekanski Massif) near the closed city of Krasnoyarsk-26. 
Table 1. Target budget estimates (\$000) for the bilateral US-Russian repository program.

\begin{tabular}{|l|r|r|r|r|r|r|r|c|}
\hline \multicolumn{1}{|c|}{ Effort topic } & FY98 & FY99 & FY00 & FY01 & FY02 & FY03 & FY04 & Totals \\
\hline Engineering feasibility & - & - & 1100 & 1100 & 1100 & 1100 & 1100 & 5500 \\
\hline Site characterization & - & 30 & 500 & 600 & 800 & 900 & 1200 & 4030 \\
\hline Underground R\&D laboratory & - & - & 400 & 500 & 800 & 1000 & 1000 & 3700 \\
\hline \hline Total \$ in Russia & 0 & 30 & 2000 & 2200 & 2700 & 3000 & 3300 & 13230 \\
\hline Total \$ in US & 100 & 370 & 800 & 900 & 900 & 800 & 700 & 4570 \\
\hline Overall Total & 100 & 400 & 2800 & 3100 & 3600 & 3800 & 4000 & 17800 \\
\hline
\end{tabular}

A unique DOE-RW management approach is required to encourage the success of the Russian program and avoid the defocusing of the project and the tendency for participants to take on nonintegrated, non-national security objectives. It is assumed that the proposed program does not directly contribute data to the Yucca Mountain licensing basis. The relatively small budgets must get to Russia to ensure success! The maximum number of Russian participants possible will be used from closed cities or the Russian Ministry of Atomic Energy (Minatom) Institutes that directly supported the Russian weapons production complex. The program may be best managed and integrated by a single lead-coordinating contractor utilizing the Yucca Mountain Project scientific expertise as appropriate.

A draft program plan planned for March 1999 as a major startup activity will be critical to configuring the scope and success of this program to achieving overall US objectives. The plan will have to accommodate the Russian interests sufficiently to be acceptable to Russia, and will require participation from experienced negotiators from the Minatom in the development of the plan. Some key issues in the plan that will be addressed and resolved jointly are discussed in detail below.

\section{Key Issues for the Repository Initiative Program}

The three major program elements are:

- Systems and engineering feasibility studies for surface and underground facility concepts

- Site characterization activities

- Underground R\&D hardrock test laboratory.

\section{Systems and engineering feasibility studies}

The Russians will examine in feasibility studies the multiple technical issues, costs, and schedules associated with proposing a single geologic repository site near the closed city of Krasnoyarsk-26 in Russia for disposal of three approved radioactive disposal forms. These forms are (1) solidified high level waste (HLW) sludges from previous production of plutonium for weapons at Krasnoyarsk-26, Tomsk, and Mayak, (2) vitrified HLW glass from reprocessing of spent fuels at Mayak, and (3) the spent RBMK fuel from power reactors. The study will also consider, as variants to the study baseline, (1) the 100-y monitored and fully retrievable geologic storage of $\mathrm{Pu}$ containing or fissile-containing forms not currently approved for disposal in Russia and (2) the use of more than a single geologic repository site in Russia. Other possible sites such as Mayak and 
Novaya Zemlya may warrant limited exploration but only as variants to the Krasnoyarsk-26 baseline study site to further examine technical issues such as transportation, packaging, and additional costs required for the characterization and development of an additional site in Russia. The identification of the specific Russian lead organizations and the best means for contracting funds is critical and must be based on actual current and past US laboratory or DOE experience derived from highly enriched uranium purchases (DOE-NE), Material Protection Control and Accounting activities (DOE-NN), Pu disposition (DOE-MD) and others. The new ISTC partnering process should be assessed as one option for getting funds into Russia.

Russian radioactive wastes and select Pu-containing or fissile-containing materials will be examined in the feasibility study for geologic disposal including factors such as costs, schedules, environmental impact considerations, and worker exposures. Three radioactive waste types are more consistent with Russian policy and practices for possible geologic disposal: (1) HLW sludges located at the three radiochemical plants at Krasnoyarsk-26, Mayak, and Tomsk from past weapons Pu production, (2) HLW glass canisters produced and located at Mayak near the RT-1 radiochemical plant, and (3) spent fuel from the various commercial RBMK reactors located at multiple sites in Russia (Fig. 1). Two additional types of Pu-containing materials not consistent with current Russian policy and practices for possible geologic disposal will be assessed for a 100y monitored and fully retrievable underground storage method as variants to the baseline case: (1) spent naval spent fuels with residual $>20 \% \mathrm{U}^{235}$ and reactor grade plutonium located in the arctic regions in Russia and (2) the VVER-1000 commercial spent fuel with residual reactor grade plutonium located in storage pools near Krasnoyarsk-26 at the proposed RT-2 radiochemical plant. A major output of the study will be the identification of costs and technical issues, including advantages and disadvantages, to the current Russian policies and practices of not proposing a single repository site. The non-technical political and public acceptance issues of consolidating radioactive materials from multiple regions to a single region may have to be addressed in some fashion. Figure 1 illustrates these wastes and fissile materials and their possible transportation flows to a single geologic repository site near Krasnoyarsk-26.

Russian participants would likely include design organizations for surface and subsurface issues (VNIPIET, VNIPIPT), the closed city nuclear weapons design institutes (VNIIEF, VNIITF), V. G. Khlopin Radium Institute (KRI), and others as specified by Minatom. The HLW sludges, HLW glass canisters, and RBMK spent fuel would be disposed of permanently. The feasibility study would also examine an option for an underground 100-y retrieval, monitored, and sealed storage concept in the same granite massive for items such as the naval spent fuels and the VVER1000 commercial spent fuel. These two nuclear materials, among others, have a proliferation risk due to plutonium or $>20 \% \mathrm{U}^{235}$ fissile material contents. The 100 -y option would allow these two materials to be retrieved and used for future energy needs in Russia should the situation change from today's projections of fissile materials needs by the Russian Federation.

\section{Site characterization activities}

These activities will be performed by Russians, but will be limited to further establishing the feasibility of a single proposed hardrock (granite) site near the closed city of Krasnoyarsk-26. The limited site characterization activities would include compiling, summarizing, and documenting the existing site data for the Krasnoyarsk region granite site. A plan for site characterization would be initiated and a draft completed based on the existing data and Russian policies and requirements. One or two previously planned, 2- to 3-km deep exploratory boreholes, for which funds are not available in Russia, would be drilled in FY00 in the proposed granite massive with partial core 


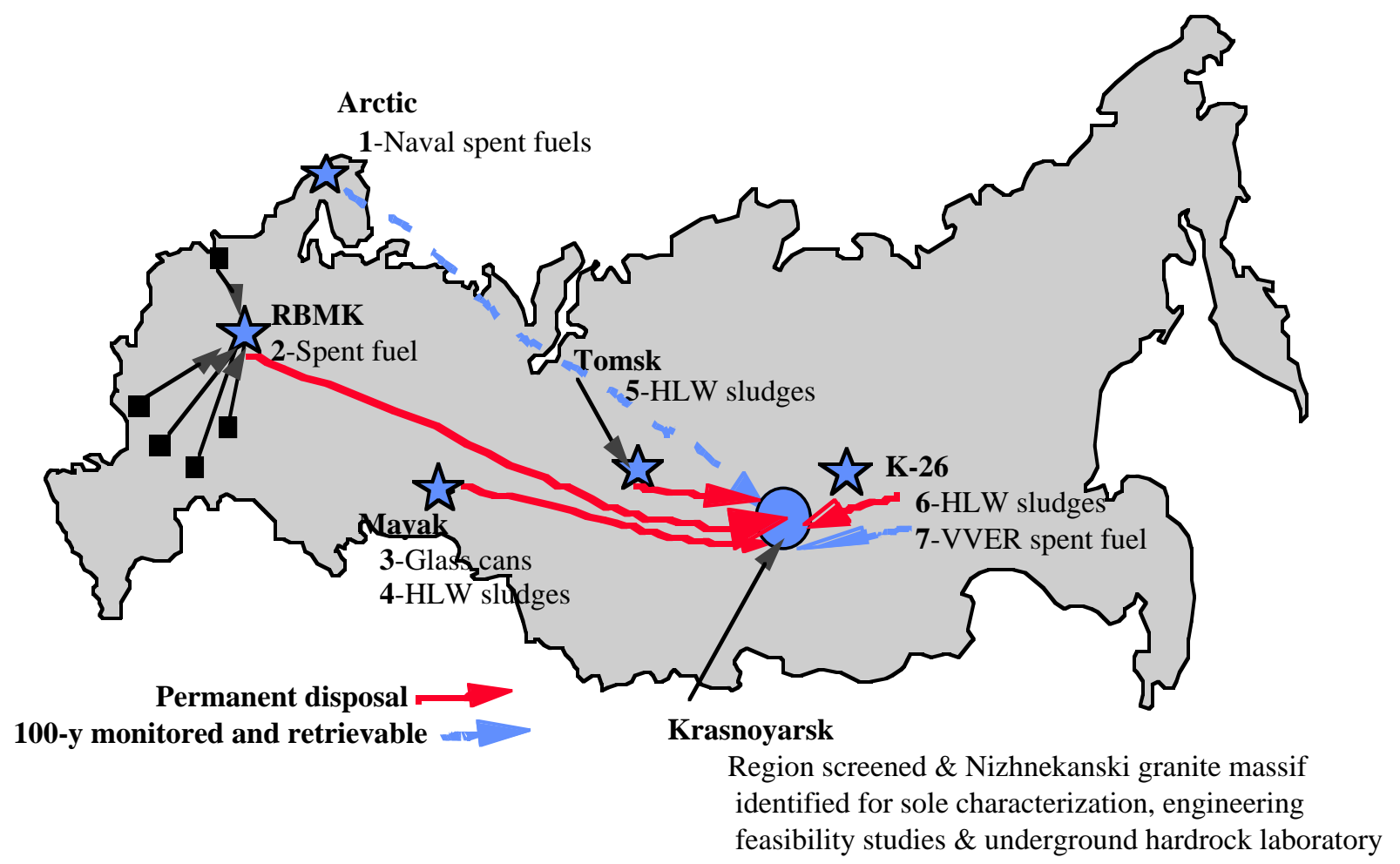

Figure 1. Russian geologic repository system for initial feasibility study. The total masses or volumes and the total curies are to be identified for the seven different types of wastes or fissile-containing materials at the various Russian sites in engineering feasibility studies.

recovery. Russian participants would likely include KRI as the scientific lead institute and the Mining Chemical Combine (MCC) as the lead industrial site.

\section{R\&D underground hardrock test laboratory}

An underground laboratory in excavated hardrock, located near the closed city of Krasnoyarsk-26, would be designed for scientific investigations associated with geologic disposal and 100-y monitored and fully retrievable underground storage. The laboratory would be modest compared to Yucca Mountain, and be more like laboratories in Canada and Sweden. Former weapons scientists from the closed cities of Arzamas and Chelyabinsk would perform the scientific tests required to develop a geologic repository and a monitored and retrieval underground storage facility. Site visits and technical exchanges with Yucca Mountain project staff would be used to establish the design concepts and requirements. Exchange visits with Sweden and Canada hardrock laboratory staff may also be proposed. The underground laboratory would define items that need to be experimentally tested in order to develop a 100-y monitored, retrievable, and sealed storage rooms in the hardrock repository for naval spent fuels, VVER-1000 commercial spent fuels, and other forms of fissile-containing materials that merit storage in a safe and secure manner until Russia's energy requirements and economic situations change. 


\section{FY99 Start-up and Planning Activities}

Planning and start-up activities will be conducted in FY99 for a formal bilateral geologic repository scientific and technical collaborations program to be started in FY00 involving DOE-RW and Minatom of the Russian Federation.

Three major deliverables will be produced in FY99:

- Bilateral scientific and technical cooperation agreement, assumed signed by the DOE Secretary and the Minatom Minister, chartering and authorizing the bilateral interactions

- Draft program plan and strategy for the bilateral program that will be finalized in early FY00

- Position paper on the method for contracting with Russian organizations in FY00.

The FY99 activities will include two meetings in Russia and one in the United States. A draft of an agreement of bilateral scientific and technical cooperation in geologic repository activities will be developed for signature in FY99 by DOE and Minatom officials. This US draft framework for studying a single site as Russia's geologic repository near the closed city of Krasnoyarsk-26 will be proposed and negotiated. Discussions in FY99 will define the specific Russian organizations and geologic repository activities of mutual interest involving the radioactive wastes, fissilecontaining materials or Pu-containing materials in Russia and land regions near Krasnoyarsk-26 and, as applicable, Novaya Zemlya and Mayak. A draft program plan and strategy will identify and document specific Russian organizations responsible for the joint interactions, initial scientific and engineering tasks of mutual interest to Minatom and DOE-RW, the specific FY00 milestones and deliverables, and linkages to the US and other international geologic repository programs. A paper will recommend, based on actual experience, the preferred method to contract with Russian organizations with the DOE-RW funds from among several known contracting options (e.g., Labto-Lab, DOE, or Lab-to-ISTC partnering, lead US Lab-to-lead Russian Institute, foreign contracts).

Work would be expected to continue into FY00 as the formal bilateral initiative and program plan were implemented. After FY99, most funds would be spent in Russia and the expenditures in the United States minimized. 